\title{
RASPBERRY CULTIVAR 'GLEN AMPLE’ GROWING UNDER HIGH TUNNELS IN LATVIA
}

\author{
Sarmīte Strautina, leva Kalniṇa, and Roberts Lūsēns \\ Latvia State Institute of Fruit-Growing, Graudu iela 1, Dobele LV-3701, LATVIA; \\ sarmite.strautina@Ivai.lv
}

Communicated by Edite Kaufmane

\begin{abstract}
Raspberries are among the most important berry crops in Latvia, but innovative solutions for their growing have not been very popular due of high implementation expenses. Use of rain shelters or other ways to protect berry production from unfavourable weather conditions can significantly increase their quality and consumer acceptance. The aim of this study was to compare different cover systems and assess their suitability for raspberry growing in Latvia. The study was conducted at the Latvia State Institute of Fruit-Growing. The cultivar 'Glen Ample' was grown in two types of high tunnels: Haygrove IV series and FVG (Folien-Vertriebs GmbH), and in open field. The temperature and air humidity regime in high tunnels promoted cane growth resulting in increased number of fruit laterals and yield, as well as weight of berries. Floricane length and number of fruiting laterals was significantly higher than in the open field. Similarly, the average berry weight and yield per row meter was significantly higher in tunnels than in open field, in both years of the evaluation.
\end{abstract}

Key words: Haygrove, Folien-Vertriebs GmbH (FVG), climatic factors, yield, berry, quality.

\section{INTRODUCTION}

Raspberries are one of the most important berry crops in Latvia, but innovative solutions for their growing have not yet been used in production. The high level of precipitation in July, which is the main harvest period, lowers the quality of berries and the volume of yield.

In order to optimise growing conditions, as well as extend the berry production season, for more than 20 years different types of covers have been used in the world, ranging from rain and wind shelters to a variety of high tunnels and greenhouses. Soil is replaced by different types of substrates, used in pots as well as in beds. The number of published studies documenting the effect of plastic cover on yield and fruit quality is relatively low, compared to research on field-grown plants (Strik, 2012). Growing conditions under light-type covers are akin to raspberry growing in the natural environment (Dale, 2012). Microclimate in such an environment (protection against wind, soil and air humidity) is beneficial to raspberry harvest potential. According to Dale (2008), climatic conditions have a major impact on the setting of flower buds in summer raspberries, for example, in British Colombia, Canada, bud initiation of the cultivar 'Meeker' continues until March while in Scotland it ends in September. There are significant differences between cultivars. Some genotypes are not very sensitive to climate, and for these no differences in bud development are observed (Dale, 2008). In experiments with autumn raspberries, the use of a wind shelter increased yield, as shoots were longer, with more internodes and fruit laterals, and the leaf surface was larger (Prive and Allain, 2000). A clear knowledge of raspberry flower initiation and dormancy indicates that the plant can be manipulated in many ways so that the fruits can be produced throughout the year. Whether these improvements can be achieved or whether they are economically practical is not known, but further research should allow plants to be manipulated to produce reliably higher yield than can be obtained presently (Dale, 2008).

As pointed out by Sønsteby and Heide (2008), shoot growth of raspberry plants requires the combination of high temperature and a long photoperiod. Shoot elongation and leaf production were strongly promoted by increasing temperature. Study of effect of temperature regime on cv. 'Glen Ample' in Norway showed that the highest growth rate was at $21{ }^{\circ} \mathrm{C}$, with a weekly increase of $23 \mathrm{~cm}$ and five new leaves. At this temperature growth of shoots continued until the beginning of autumn, with an average increase of 2-3 $\mathrm{cm}$ a week. At $9{ }^{\circ} \mathrm{C}$ growth was the slowest, and in the end of shoot growth cane length was only $85 \mathrm{~cm}$, whereas at 21 ${ }^{\circ} \mathrm{C}$ the total cane length was $350 \mathrm{~cm}$ (Sønsteby and Heide, 2008).

Vegetative growth rates are strongly promoted by high temperature (Sønsteby and Heide, 2008). The crucial tempera- 
ture for growth cession is $10{ }^{\circ} \mathrm{C}$. Photoperiodic control of growth cession was not found (Heide and Sønsteby, 2011).

The number of flowers in each inflorescence varies widely and the number of inflorescences on each fruiting lateral increases steadily from the top to the base of the main shoot (Heide and Sønsteby, 2011). Large diameter canes are more likely to produce multiple laterals (Heide and Sønsteby, 2011). On the other hand, such canes are more susceptible to winter frost than canes of medium or small diameter.

The aim of this study was to compare different cover systems and to assess their suitability for raspberry growing in Latvia.

\section{MATERIAL AND METHODS}

Two types of high tunnels were tested at the Latvia State Institute of Fruit-Growing during the years 2011-2012. The orchard is located at $56^{\circ} 370 \mathrm{~N}, 23^{\circ} 16 \quad 0 \quad \mathrm{E}$. The average annual precipitation is $560-850 \mathrm{~mm}$, which is less than in most of Latvia. The average active temperature sum during the last 20 years has been $1700-2423{ }^{\circ} \mathrm{C}$. The absolute minimum is $-36{ }^{\circ} \mathrm{C}$; yet such low temperatures were about every 5-10 years. The active temperature sum during 2011 was $2961{ }^{\circ} \mathrm{C}$ and the annual precipitation sum was $479 \mathrm{~mm}$. The active temperature sum during 2012 was $2738^{\circ} \mathrm{C}$ and the annual precipitation sum was $499.4 \mathrm{~mm}$. The highest precipitation during the growth season is typically in July, while May and August are the driest months.

Plant material and cultivation. Bare root plants of cultivar 'Glen Ample' were planted in October 2009 in the open field and in two types of tunnels: Haygrove and FVG (Folien-Vertriebs $\mathrm{GmbH}$ ). The Open Haygrove plastic tunnel was $6 \mathrm{~m}$ wide $\times 120 \mathrm{~m}$ long $\times 3.35 \mathrm{~m}$ high, covered with plastic luminiscent thermal heat block (THB) film. Thickness of the film was $150 \mu \mathrm{m}$, light transmission $87 \%$. Decrease of the light intensity by plastic cover compared to open field was $30.5 \%$.

The plastic cover was erected in the end of June before fruit ripening.

The soil type was medium sandy loam, with humus 2.3$4.6 \%$ and $\mathrm{pH}$ ( $\mathrm{KCl}$ solution) 7.2. The plant available $\mathrm{P}$ and $\mathrm{K}$ were: $\mathrm{P}_{2} \mathrm{O}_{5}-346 \mathrm{mg} \mathrm{kg}^{-1}$ and $\mathrm{K}_{2} \mathrm{O}-224-267 \mathrm{mg} \mathrm{kg}^{-1}$, respectively. Water supply was scheduled with drip irrigation; drip lines were located on the soil. Irrigation was carried out using drip pipelines with a capacity four liter per hour.

The water application was determined according to tensiometre measurement carried out twice weekly.

Irrigation was started after covers were put on, July 3 , and continued till August 23. Fertilisation $\left(12 \mathrm{~g} \mathrm{~N} \mathrm{~m}^{2}\right)$ was applied in the spring when average air temperatures reached $+6{ }^{\circ} \mathrm{C}$. Ammonium nitrate $\left(\mathrm{NH}_{4} \mathrm{NO}_{3}\right)$ was given as fertiliser.
The trial was established in randomized blocks with three replicates (plots) for each treatment (open field, FVG and Haygrove tunnels). The plants were spaced $0.5 \mathrm{~m}$ apart within rows and $3 \mathrm{~m}$ between rows, trained on an upright three-wire trellis system. Each treatment plot consisted of a 5 metre row of plants. A hedge row system with 12-15 canes per meter of row was used.

The fruits were harvested three times per week. Total yield and average berry size were recorded at harvest. Lengths of floricane, as well as number of fruit laterals, were recorded in June at time of flowering, on ten shoots from each replication. The floricanes were removed after harvest.

The following parameters were studied: yield ( $\mathrm{kg}$ per row meter); average berry weight $(\mathrm{g})$; proportion of damaged berries $(\%)$. The firmness of berries $\left(\mathrm{kg} \mathrm{cm}^{-2}\right)$ was measured on 10 berries with a stand digital penetrometer TMS-PRO (Ultra Test Mecmesin - BFG $1000 \mathrm{~N}$ ) (UK) equipped with a 3-mm diameter plunger, in three replications for FVG and Haygrove tunnels. The maximum pressure force was detected by a special programme (speed 100 $\mathrm{mm} / \mathrm{min}$ and distance in piece $-5 \mathrm{~mm}$ ). Each measurement of berry firmness was carried out three times: (1) on the picking day, (2) after 24-hour storage at room temperature, and (3) after 72-hour storage in refrigerator at $4{ }^{\circ} \mathrm{C}$ and relative air humidity $60 \%$.

During the vegetation period, the temperature ( $\max , \min$ and average), relative air humidity $(\mathrm{RH})$ ( $\max$, min and average) and precipitation ( $\mathrm{mm}$ ) for different growing systems were recorded by a LOG32 (Data-logger for temperature and humidity).

Data were subjected to ANOVA and the means were compared using a Tukey“s (HSD) test. Mathematical processing of data in MS Excel was performed to compare yield and berry weight, shoot length and raspberry fruit lateral length in different growing conditions, using ANOVA (confidence levels 95 and 99\%). Comparison of shoot length and number of fruit laterals was done using correlation analysis.

\section{RESULTS}

Temperature and relative air humidity. During the two growing seasons, air temperature differed between years and between different covers and open field. In 2011, the highest temperature was recorded in the FVG tunnel, while the lowest temperature in the open field (Fig. 1). In 2012, temperature in the Haygrove tunnel was the highest, while under the FVG tunnel and in the open field the temperature was lower and similar (Fig. 2).

During 2011-2012, relative air humidity in the FVG tunnel (77-81\%) was higher than in Haygrove (below 72-77\%), but lower than in the open field (82-84\%).

Precipitation. The highest precipitation during the two years of study was recorded in the first two decades of July 


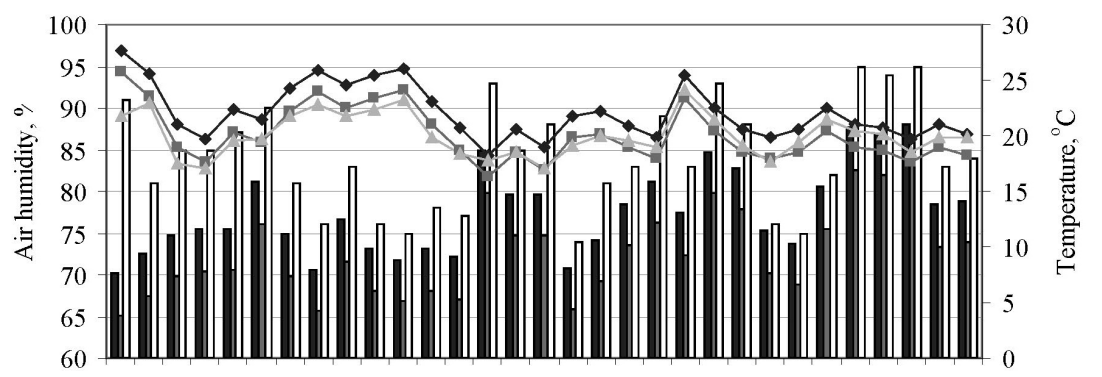

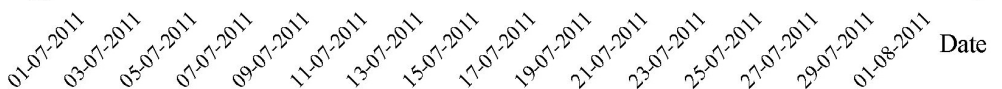

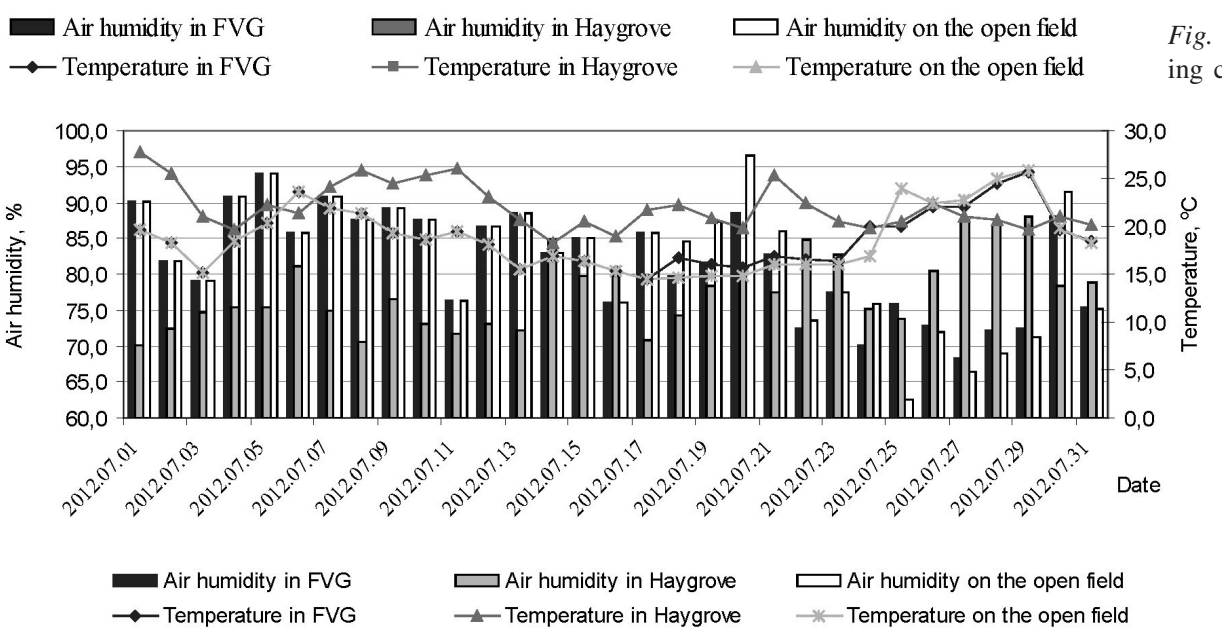

Fig. 1. Temperature and humidity in different growing conditions in 2011.
2011 (160.7 mm). In 2012, precipitation was $137.9 \mathrm{~mm}$, the greatest part of which was in the third decade of July.

Cane length and number of fruiting laterals. The floricane length and number of fruiting laterals was determined in 2012. Floricanes length was longer in the FVG tunnel and shortest in the open field. The number of fruiting laterals correlated tightly with cane length $(r=0.96)$, with the highest number of fruiting laterals in the FVG tunnel (Table 1).

Yield. The beginning of fruit ripening in 2011 was one week earlier than in 2012. In 2012, yield in the open field finished ten days earlier than in the tunnels (Table 2). The reason for the differences between 2011 and 2012 was a higher active temperature sum from the beginning of the vegetation to beginning of July in 2011, respectively $116.1{ }^{\circ} \mathrm{C}$, compared to $106{ }^{\circ} \mathrm{C}$ in 2012 .
Fig. 2. Temperature and humidity in different growing conditions in 2012.

Table 1

CANE LENGTH AND NUMBER OF FRUITING LATERALS IN 2012

\begin{tabular}{l|c|c}
\hline \multicolumn{1}{c|}{ Growing conditions } & $\begin{array}{c}\text { Number of fruiting } \\
\text { laterals }\end{array}$ & Cane length, $\mathrm{m}$ \\
\hline FVG tunnel & $14.8 \pm 3.0 \mathrm{a}$ & $1.8 \pm 0.3 \mathrm{a}$ \\
Haygrove tunnel & $13.1 \pm 2.7 \mathrm{a}$ & $1.7 \pm 0.2 \mathrm{a}$ \\
Open field & $11.5 \pm 2.5 \mathrm{~b}$ & $1.3 \pm 0.2 \mathrm{~b}$ \\
\cline { 2 - 3 } & \multicolumn{2}{|c}{$\mathrm{r}=0.96^{*}$} \\
\hline
\end{tabular}

$\mathrm{a}$; b - if different letters, significant $(P<0.01)$ between growing conditions; $*$ - significant $(P<0.01)$

There was no significant difference in yield between the two types of tunnels during the two years. Significantly lower yield was harvested in the open field $(P=0.01)(\mathrm{Ta}-$ ble 3).

RASPBERRY RIPENING TIME DYNAMICS IN DIFFERENT YEARS AND GROWING CONDITIONS

\begin{tabular}{|c|c|c|c|c|c|c|c|c|c|c|c|c|}
\hline Year & Growing conditions & 6.07 & 8.07 & 11.07 & 13.07 & 15.07 & 18.07 & 20.07 & 22.07 & 25.07 & 27.07 & 31.07 \\
\hline \multirow[t]{2}{*}{2011} & FVG tunnel & $\mathrm{Y}$ & $\mathrm{Y}$ & $\mathrm{Y}$ & $\mathrm{Y}$ & $\mathrm{Y}$ & $\mathrm{Y}$ & $\mathrm{Y}$ & $\mathrm{Y}$ & $\mathrm{Y}$ & $\mathrm{Y}$ & $\mathrm{N}$ \\
\hline & Open field & $\mathrm{Y}$ & $\mathrm{Y}$ & $\mathrm{Y}$ & $\mathrm{Y}$ & $\mathrm{Y}$ & $\mathrm{Y}$ & $\mathrm{Y}$ & $\mathrm{Y}$ & $\mathrm{Y}$ & $\mathrm{Y}$ & $\mathrm{N}$ \\
\hline \multirow[t]{3}{*}{2012} & FVG tunnel & $\mathrm{N}$ & $\mathrm{N}$ & $\mathrm{N}$ & $\mathrm{Y}$ & $\mathrm{Y}$ & $\mathrm{Y}$ & $\mathrm{Y}$ & $\mathrm{Y}$ & $\mathrm{Y}$ & $\mathrm{Y}$ & $\mathrm{Y}$ \\
\hline & Open field & $\mathrm{N}$ & $\mathrm{N}$ & $\mathrm{N}$ & $\mathrm{Y}$ & $\mathrm{Y}$ & $\mathrm{Y}$ & $\mathrm{N}$ & $\mathrm{N}$ & $\mathrm{N}$ & $\mathrm{N}$ & $\mathrm{N}$ \\
\hline & Haygrove tunnel & $\mathrm{N}$ & $\mathrm{N}$ & $\mathrm{Y}$ & Y & $\mathrm{Y}$ & $\mathrm{Y}$ & $\mathrm{Y}$ & $\mathrm{Y}$ & Y & $\mathrm{Y}$ & $\mathrm{Y}$ \\
\hline
\end{tabular}

Y- yielding; N- not yielding 
Berry firmness. In high tunnels there was a tendency of RASPBERRY AVERAGE BERRY MASS AND YIELD PER ROW METRE IN 2011 AND 2012

\begin{tabular}{l|cc|c|c}
\hline \multirow{2}{*}{ Growing conditions } & \multicolumn{2}{c|}{ One berry mass, $\mathrm{g}$} & \multicolumn{2}{c}{ Yield per row meter, kg } \\
\cline { 2 - 5 } & 2011 & 2012 & 2011 & 2012 \\
\hline FVG tunnel & $4.1 \mathrm{a}$ & $4.2 \mathrm{a}$ & $1.2 \mathrm{a}^{*}$ & $1.4 \mathrm{a}^{*}$ \\
Open field & $3.7 \mathrm{c}$ & $3.4 \mathrm{c}$ & $0.8 \mathrm{~b}^{*}$ & $0.9 \mathrm{~b}^{*}$ \\
Haygrove tunnel & $3.9 \mathrm{~b}$ & $4.0 \mathrm{~b}$ & $1.0 \mathrm{a}^{*}$ & $1.5 \mathrm{a}^{*}$
\end{tabular}
higher firmness of berries grown in FVG tunnels in 2012, although the differences were not significant $(P>0.05)$. There were no significant differences between firmness of berries from the tunnels after 72 hours storage at $4{ }^{\circ} \mathrm{C}$ (Fig. $4)$.

\section{DISCUSSION}

a; b; c - significant $(P<0.05)$ between growing conditions,

* - significant $(P<0.01)$ between years

Average berry weight. The highest average weight of one berry was in the FVG tunnel (4.1 g in year 2011 and $4.2 \mathrm{~g}$ in year 2012) during both years of the investigation. Significantly lower berry weight under open field conditions $(3.7 \mathrm{~g}$ in 2011 and $3.4 \mathrm{~g}$ in 2012) was observed (Table 3).

Yield quality. Berry quality was negatively affected by the higher temperature (above $28{ }^{\circ} \mathrm{C}$ ) and air humidity in the FVG tunnel in 2011. The berry damage caused by high temperatures in the FVG tunnel amounted to $5.1 \%$ of the total yield. The proportion of damaged berries was significantly lower in Haygrove tunnel and in the open field, $0.9 \%$ and $0.8 \%$, respectively, as there the air temperature was lower. No berry damage was observed in both types of tunnels in 2012 , when the maximal temperatures did not exceed $26{ }^{\circ} \mathrm{C}$ in all trial plots.
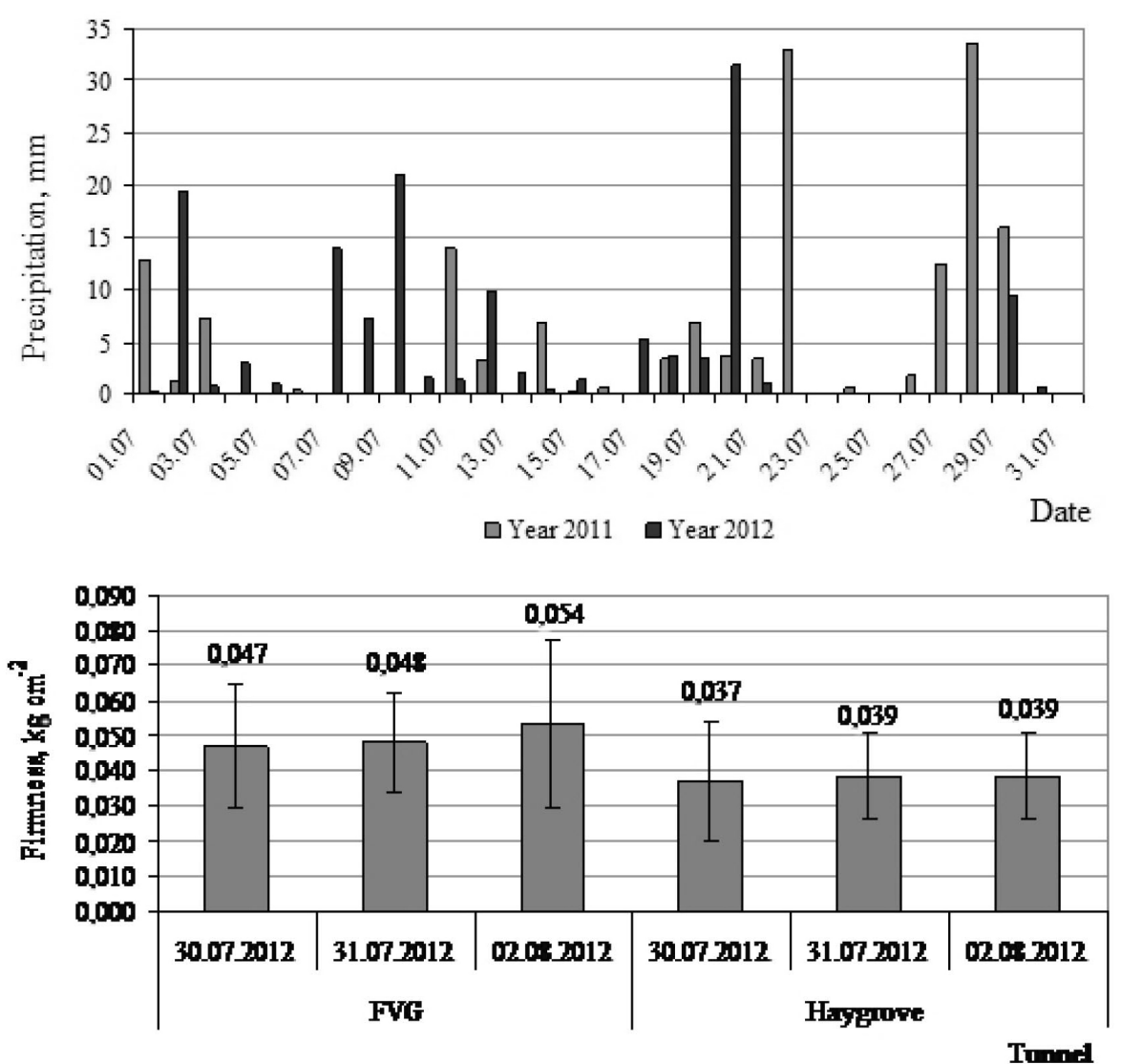

Fig. 3. Precipitation during harvest period in 2011 and 2012.
Fig. 4. Comparison of berry firmness during storage. 
The tunnels, similarly to wind shelters (Prive and Allain, 2000), improve a better microclimate, and provide more favourable conditions for cane growing, flower pollination and development of berries.

The temperature regime and relative air humidity under high tunnels influenced the weight of berries and fruit quality. A temperature above $28{ }^{\circ} \mathrm{C}$ in the FVG tunnel in 2011 caused damage to berries, compared to damage in the Haygrove tunnel or open field conditions. Higher temperatures above $24{ }^{\circ} \mathrm{C}$ decreased the firmness of berries. Although we found very few studies that agreed with our results for raspberry, experiments carried out on strawberries showed that in a temperature regime of $35^{\circ} \mathrm{C} / 20{ }^{\circ} \mathrm{C} 14 \mathrm{~h} / 10$ $\mathrm{h}$ day/night), firmness or hardness of fruits was lower (Ikeda et al., 2009). Research carried out in Norway on red raspberry 'Glen Ample' showed that the optimal temperature regime for the best compromise for yield, fruit weight, fruit quality and high concentration of biochemical compounds, was 12 to $18{ }^{\circ} \mathrm{C}$ (Rember et al., 2012). The regulation of temperature regime under plastic covers is a problem that needs an effective solution in the near future.

The differences in yield, weight of berries, and berries firmness between Haygrove and FVG tunnels were not significant, and may be to some technical aspects of the tunnels, such as the quality of film, and their length, width and height. In general, the use of plastic tunnels for raspberry growing in Latvia could be a good solution for the production of qualitative and high yield.

In conclusion, growing of raspberries in high tunnels is perspective for improvement of productivity, weight of berries and quality of berries in the climatic conditions of Latvia. The temperature and air humidity regime in high tunnels promoted cane growth, resulting in higher number of fruit laterals and yield, as well as increased weight of berries. The impact of tunnel type on raspberry yielding was not significant.

\section{ACKNOWLEDGEMENTS}

The research was financed by ERAF project: "Development and adaptation of risk reducing innovative fruit and berry growing technologies in Latvia"

Nr. 2010/0317/2DP/2.1.1.1.0/10/APIA/VIAA/142

\section{REFERENCES}

Dale, A. (2008). Raspberry production in greenhouses: Physiological aspects. Acta Hort., 777, 219-223.

Dale, A. (2012). Protected cultivation of raspberries. Acta Hort., 946, 346-354.

Heide, O. M., Sønsteby, A. (2011). Physiology of flowering and dormancy regulation in annual and biannial-fruiting red raspberry (Rubus idaeus $L$.): A review. J. Hort. Sci. Biotechnol., 86 (5), 433-442.

Ikeda, T., Yamazaki, K., Kumakura, H., Hamamoto, H. (2009). Effect of high temperature on fruit quality of pot grown strawberry plants. Proceedings of the Sixth International Strawberry Symposium. Acta Hort., 842, 679-682.

Prive, J. P., Allain, N. (2000). Wind reduces growth and yield but not net leaf photosunthesis of primocane-fruiting red raspberries (Rubus idaeus L.) in the establishment years. Can. J. Plant. Sci., 80, 841-847.

Remberg, S. F., Sønsteby, A., Wold, A. B., Heide, O. M. (2012). Influence of temperature on berry quality of 'Glen Ample' red raspberry. Proceedings of the 28th International Berry Symposium. Acta Hort., 926, 705-711.

Sønsteby, A., Heide, O. M. (2008). Enviromental control of growth and flowering of Rubus idaeus L. cv. Glen Ample. Hort. Sci. 117, 249-256.

Strik, B. C. (2012). Flowering and fruiting on command in berry crops. XXVIII International Horticultural Congress on Science and Horticulture for People (IHC2010): International Symposium on Berries: From Genomics to Sustainable Production, Quality and Health. Acta Hort., 926, $197-214$.

Vanden Heuval, J. E., Sullivan, J. A., Proctor, J. T. A. (2000). Cane stabilization improves yield of red raspberry Rubus idaeus L. Hort. Sci., 35, 181-183.

Vanden Heuvel, J. E., Sullivan, J. A., Proctor, J. T. A. (2000). Trellising system and cane density affect yield and fruit quality of red raspberry. Hort. Sci., 35 (7), 1215-1219.

Received 21 March 2013

\section{AVEN̦U ŠĶIRNES 'GLEN AMPLE’ AUDZĒĚŠANA AUGSTAJOS TUNEḶOS LATVIJĀ}

Plēves pārklāji un augstie tuneḷi ir viena no iespējām kā pasargāt aveņu ražu no lietus un citiem nelabvēlīgiem laika apstākḷiem, tādējādi būtiski uzlabojot tās kvalitāti. Kaut gan Latvijā avenes ir viena no nozīmīgākajām ogu kultūrām, jaunas un modernas tehnoloğijas to audzēěanā tiek ieviestas ḷoti lēni. Galvenie iemesli ir augstās ierīkošanas izmaksas un mazais tirgus piesātinājums ar aveṇu ogu produkciju. Lai veicinātu jauno audzēšanas tehnoloğiju ieviešanu, kuras uzlabo gan aveṇu ražību, gan ogu kvalitāti, Latvijas Valsts aug̣̣kopības institūtā tika veikts pētījums par divu veidu augsto plēves tuneḷu: FVG un Haygrove izmantošanas iespējām aveņu audzēšanā Latvijā. Kā modeḷškirne tika izvēlēta šḳirne 'Glen Ample', kas ir Eiropā plaši audzēta komercškirne un piemērota audzēšanai augstajos plēves tuneḷos. Temperatūra un relatīvais gaisa mitrums augstajos plēves tuneḷos veicināja dzinumu augšanu garumā, lielāku augḷzaru skaita veidošanos, kā arī lielāku ogu masu. Augḷzaru skaits un ražojošo dzinumu garums, raža un ogu masa gan FVG, gan Haygrove tunelī bija būtiski lielāki nekā atklātā laukā. 